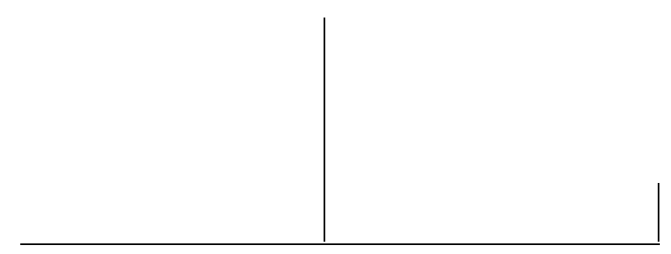

Rev. Latinoam. Psicopat. Fund., VIII, 4, 665-678

\title{
O fascínio do ver e a angústia do olhar: sobre o corpo e a subjetividade*
}

\author{
Luciana Almeida Motta \\ Tania Rivera
}

Tecendo um diálogo entre um caso clínico e uma obra de arte, o artigo aborda a questão do olhar e da imagem corporal na estruturação da subjetividade. Propõe-se que o olhar sobre o corpo evocaria duas dimensões: fascínio e angústia, remetendo respectivamente à identificação e à alteridade, fundamentais para a constituição do humano.

Palavras-chave: Psicanálise, corpo, olhar, fascínio, angústia

* Este trabalho recebeu Menção Honrosa do Prêmio Internacional Pierre Fédida de Ensaios Inéditos de Psicopatologia Fundamental - 2004, concedida pela Associação Universitária de Pesquisa em Psicopatologia Fundamental. 


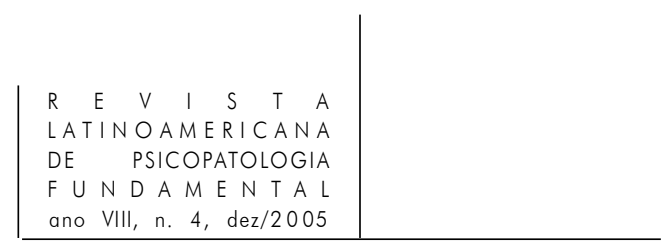

Meu corpo não é meu corpo, é ilusão de outro ser Carlos Drummond de Andrade

Maria, uma adolescente de 17 anos, chega ao serviço de psicologia de um hospital queixando-se de manifestações corporais que a perturbam desde os 14 anos de idade. Incitada a falar, ela descreve minuciosamente o retrato de um corpo que a passa em revulsão, funcionando à sua revelia.

Ela é recorrentemente acometida por crises que conjugam dor e gozo: o ar lhe falta, o coração dispara, toda a carne fica em um estado de suspensão, de encontro com a morte. Estes episódios, que chegam a durar três dias, são precedidos por uma sensação de agitação crescente e vêm acompanhados de dores intensas e difusas que se deslocam pelo corpo. Cada crise culmina em uma tentativa de suicídio, por superdosagem de medicação psicotrópica. Este ritual se encerra por um despertar de Maria que, ao mesmo tempo em que sofre por estar viva, constata com júbilo a preocupação de familiares e amigos.

Paralelamente à manifestação da primeira crise, observou-se a ocorrência de prurido em toda a superfície corporal, ocorrendo principalmente à noite, sucedido pelo surgimento de pápulas eritomatosas recobertas por crostas, predominantemente nas pernas. Não se chegou a um diagnóstico preciso acerca destes sintomas, e a equipe médica atribuiu a fatores psicogênicos o seu desencadeamento. Estas manchas na pele, aliadas às cicatrizes decorrentes de um período em que Maria se autoflagelava, provocando cortes pelo corpo, participam de um jogo em que ela alterna uma tentativa de ocultação e uma triunfante exibição de suas marcas corporais.

A sensação de habitar um corpo estranho - tema recorrente no discurso da analisante - teve sua concretização durante um episódio em que Maria afirma ter sido possuída por um espírito. Enquanto este a ocupava, ela não era capaz de emitir sons ou de controlar seus braços, que a espancaram violentamente. Ela teve sua roupa rasgada e se recorda do esforço para expulsar o invasor, por meio de seus pensamentos. Com esta coreografia vacilante, Maria apresenta uma cena de sedução: ela se desnuda e se esquiva de algo que invade seu corpo, mostrando uma confusa oposição entre passividade e atividade, visto que estes 


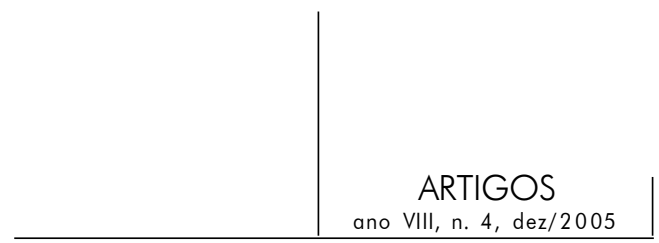

movimentos disruptivos são realizados por seres - ela própria e o "espírito" - que habitam o mesmo espaço. Este episódio aproxima-se de sua descrição das crises, pelo forte conteúdo erótico e pela conjugação entre sedução, fascínio, esquiva e angústia, encenados no corpo.

Esta sensação de invasão por um outro também se faz presente nos contos que Maria costuma escrever. Ela se vê como instrumento utilizado pelos espíritos para narrar suas histórias, a ponto de não ser capaz de determinar com precisão o nível de autoria que exerce nos materiais que produz. Esta confusão entre si própria e o universo espiritual sugere a idéia de um eu fragilmente delimitado, que ressoa na incerteza que ela apresenta quanto aos limites de seu corpo.

Estas peculiaridades de sua estruturação corporal e subjetiva remetem à ausência de um efetivo investimento do outro em um tempo inicial de constituição. Maria foi abandonada pela mãe aos três meses de vida, sendo criada em orfanatos e em casas de amigos do pai. Este mantinha um limitado contato com ela e não tinha condições de criá-la, por ser alcoolista. Aos três anos de idade a criança ficou muito doente, correndo risco de vida, devido à carência dos cuidados básicos necessários à sua sobrevivência. Neste período ela foi adotada por uma tia e seu marido, que considera seus pais. Maria afirma que se ressentia fortemente de sua infância, mas por volta dos 14 anos, época que coincide com o início dos sintomas, isso deixou de incomodá-la. Atualmente tem se esforçado por estabelecer um vínculo afetivo com o pai biológico, porém sente indiferença pela genitora, recusando-se a conhecê-la.

As questões suscitadas por este caso clínico serão trabalhadas em diálogo com a obra Self-Portrait (1971), do artista inglês Francis Bacon. Este encontro deve-se à possibilidade de aproximação entre a descrição de Maria sobre seu próprio corpo e o corpo retratado pelo artista na obra de arte mencionada, que se encontra reproduzida a seguir.

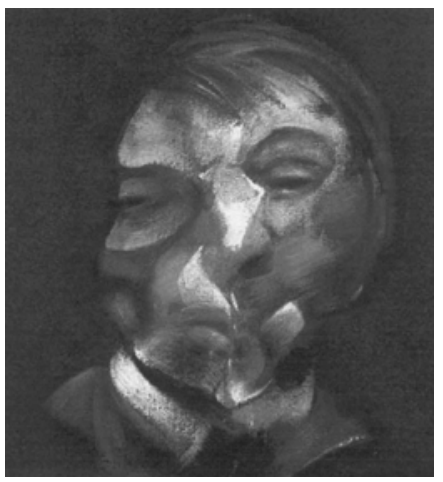

Figura 1: Self-Portrait, 1971 


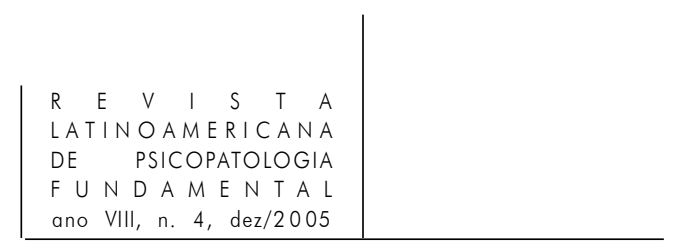

A tela de Bacon e o corpo de Maria apresentam-se como retratos de uma anatomia reconfigurada, colocando em cena uma dimensão de desconhecimento do corpo. Propõe-se assim uma aproximação entre arte e psicanálise, que reconhece que entre estes termos há certamente um "hiato, uma impossibilidade de conjunção (...), mas este encontro manco, justamente por fracassar, deixa nos dois campos profundas marcas, incitando-os a transformações e criações, em um jogo de influências mútuas” (Rivera, 2002, p. 22). Serão explorados os elementos resultantes desta interpenetração entre arte e psicanálise, a fim de desenvolver as questões que uma produção cultural, assim como o trabalho clínico, colocam à teorização psicanalítica.

\section{Auto-retrato de um corpo outro}

Um auto-retrato, como o apresentado por Francis Bacon (1971), pode ser considerado como um recorte momentâneo da biografia do corpo, efetuado pelo artista. Assim como o escritor que se propõe a narrar sua história, o artista, mesmo que o queira, não pode revelar sobre seu corpo muito mais que uma verdade parcial, pois entre este e sua representação há sempre um hiato constituído pelo que há de inapreensível no corpo, por aquilo que a imagem não revela, e mais, pelo indizível que ela recobre. Esta ruptura que o auto-retrato encena aponta para "o ruído de rasgo no invólucro liso da imagem" (Barthes, 1977, p. 19), ou seja, para a dimensão de estranhamento que o corpo comporta. O Self-Portrait coloca em cena estas questões, figurando o limite tenso que se instala entre auto e alter-retrato, em um retrato do corpo como outro.

A obra nos faz vacilar entre duas posições: reconhecimento e espanto. Bacon nos deixa conhecer os traços que singularizam seu rosto, mas nos impede de nomeá-los, em função da oscilação entre inscrição de marcas e inscrição de um apagamento das mesmas que ele opera em uma só pincelada.

Há contornos neste rosto, mas eles parecem desfeitos por manchas, o que os tornam incertos, sem formas definidas, fugidios. Estas manchas lembram as marcas no corpo de Maria que, quando expostas ao olhar, provocam uma sensação de estupor.

Entre os dois lados da face de Bacon não há simetria, apenas uma frágil harmonia desestabilizada pela diferença entre as proporções. Neste conjunto, o que mais chama a atenção são os olhos, situados dentro de uma cavidade que se mostra como o único elemento firmemente delimitado do retrato. Esta depressãoabismo abriga, sob a pálpebra caída, olhos absolutamente negros, sem íris nem 


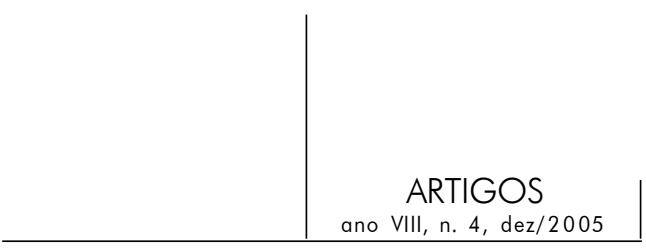

córnea, o que nos faz ter a sensação de que na verdade não há olhos dentro da cavidade, mas vazio, abismo sobre abismo.

Pode-se dizer que Bacon (1971) faz um re-trato de seu rosto, efetua um trabalho que apresenta como resultado uma condensação, em uma mesma figura, de sustentação e queda da imagem, manifestando em seu rosto o familiar dos contornos humanos e o horror do desaparecimento dos mesmos.

Os auto-retratos compostos pelo artista e pelo discurso de Maria evidenciam corpos que, ao olhar, se deixam reconhecer em sua singularidade, ao mesmo tempo em que provocam uma quebra, uma ruptura, um intervalo no familiar, colocando em cena o desconhecido.

Surge assim a questão que move esta discussão: como um olhar que se deixa cindir em duas categorias - uma que desconhece e outra que reafirma a imagem corporal - produziria seus efeitos sobre os processos de subjetivação? Considerando a definição de Freud (1919) para o Unheimliche, segundo a qual este é algo que apresenta na sua etimologia tanto a idéia de horror, assustador, quanto a de conhecido e familiar, propõe-se que o olhar sobre o corpo também evocaria duas dimensões contrárias: a angústia e o fascínio, noções que aqui serão remetidas respectivamente à identificação e à alteridade, fundamentais para a constituição do humano. Estas duas categorias dizem respeito ao olhar e serão tratadas a partir do caráter de estranheza do corpo, entrelaçando o caso de Maria à obra mencionada.

\section{O Eu como efeito de fascínio}

"O que nos é dado por um contato à distância é a imagem, e o fascínio é a paixão da imagem” (Blanchot, 1955, p. 23). É neste sentido que o fascínio será aqui considerado. Veremos que o fascínio assim entendido abre possibilidades para uma articulação entre a imagem, o olhar e o amor, noções importantes para a estruturação do eu em suas relações com o corpo.

Freud (1914) aponta que o eu não se encontra presente desde o início, sendo necessário que algo se adicione ao auto-erotismo para que ele se estruture. Ele utiliza o termo narcisismo para designar este momento, que ocorre em uma fase situada entre o auto-erotismo e o investimento nas relações objetais. Nesta fase, as pulsões, que no auto-erotismo eram parciais, unificam-se e dirigem-se a um único objeto: o eu. Freud (1911), ao tratar do narcisismo no texto sobre o Presidente Schreber, faz a seguinte afirmação:

Essa fase (...) pode, talvez, ser indispensável normalmente; mas parece que muitas pessoas se demoram por tempo inusitadamente longo nesse estado e que 


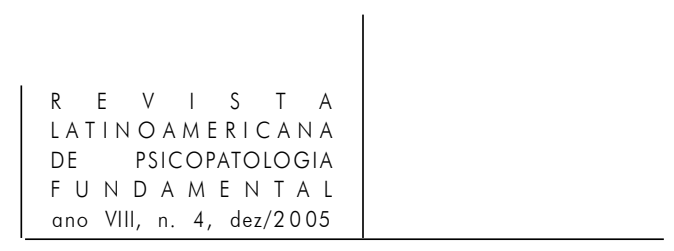

muitas de suas características são por elas transportadas para os estádios posteriores de seu desenvolvimento. (p. 68)

Ele opera uma relação entre a idéia de momento constitutivo e permanência do investimento libidinal no eu em outras fases da vida, distinguindo as noções de narcisismo primário e secundário. Estes conceitos indicam que o eu seria uma instância que conjugaria estas dimensões temporais, visto que o momento inicial de constituição não assegura a sua permanência, sendo necessários novos investimentos.

Para Freud (1914), o narcisismo designa um comportamento pelo qual o indivíduo "trata seu próprio corpo da mesma forma pela qual o corpo de um objeto sexual é comumente tratado” (p. 81). Esse amor de si próprio coloca em cena a relação que Freud estabelece entre o conceito e o mito de Narciso, no qual este se apaixona pela imagem de seu corpo. Este entrecruzamento da psicanálise e da mitologia inscreve suas marcas sobre o termo, levando-nos a observar mais atentamente este mito, a fim de apreender as peculiaridades que a noção de narcisismo impõe sobre o processo de subjetivação e a estruturação do corpo.

O filólogo Junito de Souza Brandão (2002) relaciona a palavra Narciso ao termo grego nárke, que significa entorpecimento, torpor, sensações que Narciso, em função da sua rara beleza, provocava em seus admiradores. Dentre estes estavam as ninfas que, furiosas por serem sempre repelidas pelo rapaz, pedem vingança à Nêmeses, que o condena a “amar um amor impossível” (p. 178). Narciso encontra o seu destino, de amor e morte, ao ver a sua imagem pela primeira vez refletida nas águas plácidas de um lago, conforme os versos de Ovídio (em Brandão, 2002):

Deitou-se e tentando matar a sede, /Outra mais forte achou. Enquanto bebia, /Viu-se na água e ficou embevecido com a própria imagem. /Julga corpo, o que é sombra, e a sombra adora. /Extasiado diante de si mesmo, sem mover-se do lugar, /O rosto fixo, Narciso parece uma estátua de mármore de Paros. (...) Estirado na relva opaca, não se cansa de olhar seu falso enlevo, /E por seus próprios olhos morre de amor. (p. 180)

Narciso, que ignorava o outro, é surpreendido pela beleza de seu próprio corpo, perfeitamente refletido em um espelho de águas jamais tocadas. Ele se vê entorpecido, apaixonado por uma imagem que traga seu olhar, o paralisa, capturando-o até a morte. É este corpo que o fascina, que determina seu destino.

É esse efeito de fascínio provocado pelo olhar, ao se lançar para a imagem do corpo, que possibilita o investimento libidinal necessário para a constituição do eu, este “órgão formidável do desconhecimento” (Barthes, 1977, p. 51). No entanto, Narciso nos ensina que se a imagem não for fissurada, se o fascínio 


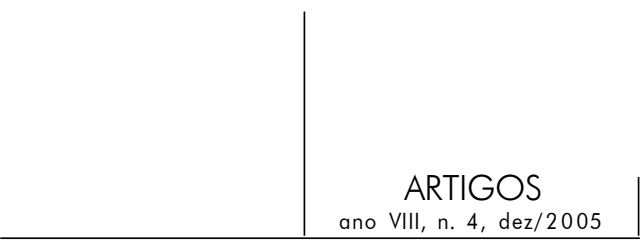

persistir a ponto de cristalizar a libido no eu, impedindo que ela se volte para o mundo, é a morte que desponta.

Tal articulação entre amor e morte no fascínio da imagem do corpo aparece nas elaborações de Freud (1919) sobre o duplo. Ele surgiria para garantir ao eu a sua existência e permanência e se transformaria subitamente em "estranho anunciador da morte" (p. 252). Este duplo, semelhante, retrato do mesmo sendo outro, como na imagem de Narciso no lago, faz-se sempre acompanhar do estranho, por apresentar no mesmo objeto o reconhecimento, o familiar, e o horror do que não se encaixa, do que insiste ou, em última instância, da própria morte.

O estádio do espelho, elaborado por Lacan (1949), também nos traz importantes elementos acerca do fascínio exercido pelo duplo. Nele, a criança, em um estado de prematuração, incoordenação motora e impotência, antecipa, "numa azáfama jubilatória” (p. 97), a sua unidade corporal pela identificação com a imagem do semelhante. Nesta experiência, que tem como protótipo o encontro do bebê com sua imagem no espelho, se constituiria o primeiro esboço do eu.

No entanto, a imagem que se mostra no espelho apresenta um caráter de engodo, pois o bebê antecipa sua estruturação e adquire a idéia de si como uma unidade, ao se reconhecer em uma imagem que se apresenta invertida, denunciando a distância entre o reflexo e aquilo que é refletido. $\mathrm{O}$ eu estruturase, portanto, em uma "linha de ficção" (ibid., p. 98), uma miragem que toma o semelhante como mesmo. Narciso e a criança diante do espelho possuem, assim, algo em comum: fascinados, ambos caem na armadilha da imagem, apontando para o paradoxo que ela apresenta entre identidade e alteridade. Narciso apaixonase por si próprio, com a ilusão de que ama um outro; a criança, por sua vez, alcança um estado de júbilo ao tomar o outro como mesmo.

Outro aspecto a ser considerado é que a imagem é sempre completa, já que ela não pode retratar aquilo que falta. $\mathrm{O}$ júbilo da criança ao se reconhecer no espelho remeteria ao encobrimento da falta, à "satisfação narcísica de saber-se um corpo" (Quinet, 2002, p. 128), e também de saber-se humano, identificado ao semelhante, como indica Lacan (1946) ao dizer que "o homem é escravo (...) dessa paixão de ser um homem, que é a paixão da alma por excelência: o narcisismo" (p. 189).

No entanto, esta satisfação narcísica só se completa a partir do olhar do outro, do terceiro para o qual a criança se volta para confirmar a imagem que reconhece no espelho. Lacan (1966) se refere a isto no texto "De nossos antecedentes”, ao fazer a seguinte afirmação:

O que se manipula no triunfo da assunção da imagem do corpo no espelho é o mais evanescente dos objetos, que só aparece à margem: a troca dos olhares, manifesta na medida em que a criança se volta para aquele que, de algum modo, a assiste, nem que seja apenas por assistir a sua brincadeira. (p. 74) 


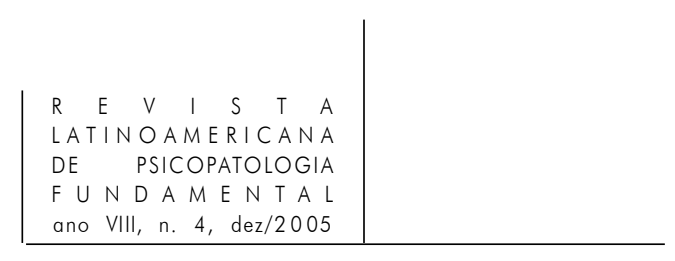

Deste modo, o olhar, objeto evanescente, já aponta para a inscrição do desejo no campo do outro, fazendo furo na imagem, interrompendo o fascínio que captura a criança na imagem do espelho, para que ela possa voltar-se ao outro. Assim, “... a mãe gratificante me mostra o espelho, a Imagem, e me fala: 'é você'. Mas a mãe muda não me diz o que sou: não tenho mais base, flutuo dolorosamente, sem existência”. Com esta passagem, Barthes (1977, p. 151) nos lembra que é a imagem do corpo que dá o sentido de unidade, de "eu sou" para a criança, mas isso, apesar de essencial, não é suficiente, pois seria preciso que o olhar do outro desse alguma consistência a este ser.

Esta consistência, nunca plenamente alcançada, tem seus limites ainda mais evidenciados no caso clínico relatado, pela fragilidade de um eu dissolvido na sensação de ser tomado por "espíritos". Maria tenta fixar o corpo, ancorar esta fluidez, pelas cicatrizes e crostas que marcam agressivamente a pele, esta camada continente e protetora do corpo, o envelope que, apesar de perfurado, oferece a ele algum limite. As cicatrizes dão notícias dos cortes produzidos por Maria, representando assim a fragilidade das bordas que separam interior e exterior, ao passo que as crostas se constituiriam como tentativas de obturar estes furos, ao recobrirem a pele com uma sobreposição de tecidos.

Além disso, pode-se pensar que Maria busca retomar repetidamente o momento de estruturação do eu, ao atrair para as marcas o olhar do próximo. Com isso, ela invoca a confirmação do outro no que se refere à percepção de sua imagem corporal, o que se daria como reedições do que se passa no estádio do espelho.

É nesse movimento que se dão suas tentativas de suicídio, visto que é na possibilidade de encontro com a morte que ela captura, de forma mais efetiva, o investimento do semelhante, incitado a reafirmar a existência e a importância de Maria no mundo. Estes momentos são vivenciados com júbilo, de modo que o contato com a transitoriedade do corpo o valoriza e possibilita uma sensação de identidade e unidade.

O narcisismo e o estádio do espelho apontam, assim, para o lugar do corpo na constituição do eu, em um encontro que é desencontro, que se faz pela via da miragem, da ficção, do engano. O eu é estruturado, deste modo, em um entre: entre outro e mesmo, ilusão de unidade e reconhecimento da falta, identidade e alteridade.

Estes aspectos paradoxais presentes na relação entre o eu e o corpo são representados na obra de Bacon (1971), que parece retratar o instante exato entre o aparecimento da imagem e seu desaparecimento, pois a unidade da face se faz notar ainda que, ao mesmo tempo, as formas se derretam a partir das manchas. Essa obra figura a inscrição e o apagamento da imagem, lembrando o quanto o seu caráter de miragem a torna frágil. Assim, o fascínio dá lugar à angústia diante 


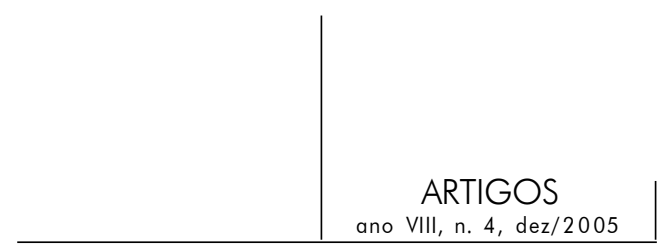

do desfalecimento da imagem e da incerteza quanto à permanência do eu, que perde por um momento a ilusão que o sustenta.

Esta fragilidade do eu é colocada em cena, de modo igualmente abrupto, nas crises vivenciadas por Maria. Nelas, todo o jogo de sedução empreendido pela paciente na tentativa de capturar o olhar de um outro que lhe emprestaria consistência é colocado em suspenso. Ele é interrompido pelo atravessamento de algo do corpo que se configura como enigma, destituindo o eu do lugar em que se encontrava e fazendo irromper a angústia.

Destaca-se assim a importância da temporalidade na articulação entre fascínio e angústia, pois vemos com a obra de Bacon (1971) e com o caso clínico, que a passagem à angústia se dá num corte, num instante que perfura a imagem e efetua a cisão do eu, momento traumático sempre reeditado. Lacan, ao tratar da angústia, aponta para esta dimensão temporal, como se nota na seguinte afirmação: “...'de repente', 'subitamente', vocês sempre encontrarão estes termos no momento da entrada do fenômeno do unheimlich. (...) No levantar das cortinas, é este curto momento rapidamente extinto da angústia”. ${ }^{1}$

\section{A angústia como sinal da ausência}

O auto-retrato e Maria nos ensinam que para além do fascínio, no momento de queda da imagem, surge a angústia. Se o fascínio corresponde à sustentação da imagem, a angústia assinala sua ruptura. O posicionamento de Lacan $^{2}$ diante desta questão indica um caminho para a abordagem da mesma:

O corpo não nos é dado de maneira pura e simples em nosso espelho, inclusive nesta experiência do espelho pode chegar um momento em que essa imagem especular que cremos ter se modifica: o que temos frente a nós mesmos, nossa estrutura, nossa cara, nosso par de olhos, deixa surgir a dimensão de nosso próprio olhar e o valor da imagem começa então a mudar, sobretudo se há um momento em que este olhar que aparece no espelho começa a nos olhar; initium, aura, aurora de um sentimento de estranheza que é porta aberta para a angústia.

Nota-se que Lacan destaca duas dimensões do olhar: o olhar de quem vê, situado ao nível dos olhos, e o olhar que se volta da cena e surpreende o sujeito, que não mais olha, mas se vê olhado. Instala-se assim uma diferença entre a visão

1. Seminário X. A angústia (transcrição inédita), aula de 19 de dezembro de 1962.

2. Ibid., aula de 9 de janeiro de 1963. 


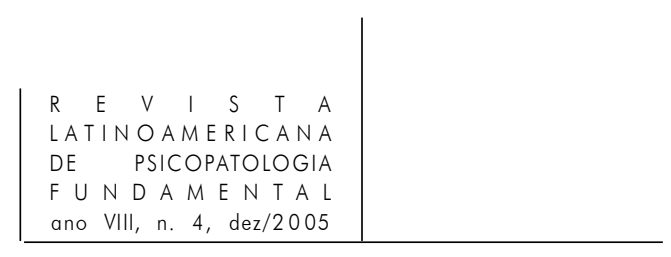

e o olhar, no sentido de que "aquilo que escapa ao campo da visão inaugura o que é da ordem do olhar, do desejo de ver. (...) O olhar está fora de qualquer captura especular” (Scheinkman, 1995, p. 82). O termo punctum, proposto por Barthes (1984), relaciona-se a esta idéia, definindo-se como algo que parte da cena e fere o sujeito que, deste modo, se vê surpreendentemente olhado, atingido por uma lança ou, como já dizia Lacan (1964, p. 83), "por um objeto punctiforme, (...) com o qual o sujeito confunde seu próprio desfalecimento".

A maneira como se configuram os olhos no Self-Portrait (1971) também nos leva a considerar esta questão, tendo em vista que situamos o corpo retratado em um momento de transição, de báscula, de oscilação, em que vai se dando o apagamento da imagem, e o que nos chama a atenção, nos faz punctum, são os olhos que não mais podem ver, mas situam uma ausência. Esta aponta para a dimensão do olhar, por deixar descoberto o abismo em que os olhos deveriam se situar, o buraco negro sob as pálpebras, colocando em cena a proposta de que “ali onde falta a visão, advém o olhar” (Scheinkman, 1995, p. 91).

Os olhos, segundo esta perspectiva, seriam a "porta do engano", para empregar a expressão de Guimarães Rosa (1962, p. 120). Eles sustentam a ilusão da imagem e o efeito de fascínio, enquanto o olhar remete para além do imaginário, para além da permanência do eu, apontando para o vazio, a morte, a angústia, que faria advir o sujeito nos intervalos em que a imagem desfalece. $\mathrm{O}$ sujeito, deste modo, é irredutível à imagem, representando-se na ausência, conforme indica Lacan, ao se referir ao Unheimliche: “... o homem encontra sua casa em um ponto situado no Outro, mais além da imagem da qual somos feitos, e esse lugar representa a ausência em que nos encontramos”. ${ }^{3}$

Freud (1926 [1925]) define a angústia como um afeto que sinaliza a eminência de um perigo e situa a sua origem no eu. Lacan, ${ }^{4}$ a partir disso, propõe que há uma estrutura da angústia, visto que esta se apresenta enquadrada em certos limites que definem o seu lugar, e este "lugar eleito da angústia", diz ele, "se situa em uma certa borda, uma certa abertura, uma certa hiância onde a constituição da imagem especular mostra seu limite”. ${ }^{5}$ Estas considerações levamno a nomear a angústia como um "fenômeno de borda", ${ }^{6}$ como o "corte que se abre e que deixa aparecer (...) o inesperado, a visita, a novidade”, 7 ou seja, o estranho, aquilo que faz bascular o reconhecimento da imagem especular.

3. Seminário X. A angústia (transcrição inédita), aula de 5 de dezembro de 1962.

4. Ibid., aula de 19 de dezembro de 1962.

5. Ibid., aula de 16 de janeiro de 1963.

6. Ibid., aula de 23 de janeiro de 1963.

7. Ibid., aula de 19 de dezembro de 1962. 


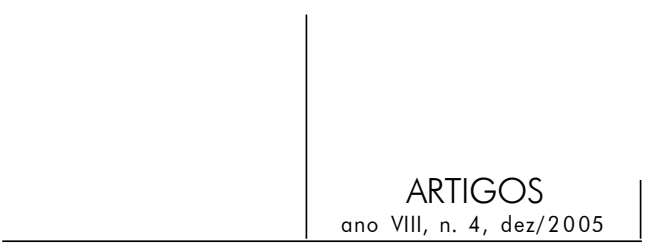

Esta discussão sobre o olhar, a angústia e a queda da imagem do corpo se reflete na seguinte passagem: “Quando o homem, buscando o vazio do pensamento, avança para o lampejo sem sombras do espaço imaginário, abstendose até mesmo de esperar o que daí irá surgir, um espelho sem brilho mostra-lhe uma superfície em que nada se reflete” (Lacan, 1946, p. 189). Assim, a angústia indica aquilo que do corpo escapa, ela trata do corpo em negativo, da ausência que nele se inscreve, daquilo que se marca no corpo como castração e que não é passível de ser figurado na imagem. Se no seu aspecto fascinante o corpo possibilita a constituição do eu, na sua dimensão de angústia ele o faz decair, fazendo despontar, fugidiamente, o sujeito.

As manchas na obra de Bacon (1971), que conferem a sensação de instabilidade à imagem, parecem representar justamente esta impossibilidade de apreendê-la, no momento em que o olhar se presentifica. Sobre a função da mancha, Quinet (2002) afirma que ela "representa o olhar, mancha o espetáculo narcisista do mundo, desvendando o segredo da imagem” (p. 137). O SelfPortrait marca aquilo que escapa do domínio da visão, suscitando incerteza e impossibilidade de captura e reconhecimento da imagem, mas, ao mesmo tempo, figurando de forma evanescente o sujeito. O olhar, como lembra Quinet, "surge quando o sujeito se torna mancha no quadro" (idem).

Tal figuração das manchas relaciona-se, portanto, à idéia de despersonalização, conforme se nota na seguinte observação de Lacan: “... é ao não se reconhecer no espelho ou o que quer que seja de análogo, que o sujeito começa a ser apreendido pela vacilação despersonalizante”. ${ }^{8}$ Freud (1936), no artigo "Um distúrbio de memória na acrópole”, conceitua a despersonalização como o sentimento de que uma parte do próprio eu é estranha, o que provoca, segundo ele, “a extraordinária situação de ‘double conscience’ que se descreve mais corretamente como 'personalidade dividida'” (p. 242). O surgimento do estranho no espelho se acompanha de angústia, na medida em que reafirma uma cisão no eu. Os episódios em que Maria tem a percepção de ser influenciada ou invadida por espíritos implicam, da mesma forma, em uma divisão do eu que, no relato da paciente, se concretiza como um duelo com o intruso que a invade, no qual ela termina por espancar a si própria.

Isso que invade subitamente e põe fora de cena a conhecida imagem do eu não é mais que uma "pulsação”, como sublinha Erik Porge (1996, p. 502), uma "fenda por onde algo de não-sabido - de inconsciente - se abre e se fecha assim que é apreendido pela consciência. (...) O sujeito não é nada de substancial, ele é o momento de eclipse que se manifesta num equívoco” (idem).

8. Seminário X. A angústia (transcrição inédita), aula de 23 de janeiro de 1963. 


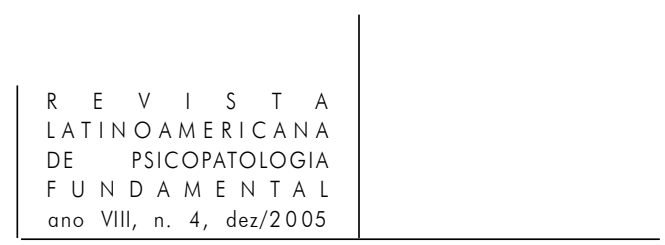

Desta forma, o desconhecido e o familiar do corpo encontram na subjetividade uma divisão correspondente: o inconsciente emerge nos intervalos da consciência, inaugurando na psicanálise uma subjetividade irremediavelmente cindida. Isto remete à observação de Freud de que "o inconsciente é certamente o verdadeiro intermediário entre o somático e o psíquico, sendo talvez o missing link tão procurado” (Freud apud Assoun, 1996, p. 174).

Nas articulações aqui traçadas, a partir do caso clínico e da obra de arte, observa-se que o alcance que o olhar sobre o corpo tem sobre os processos de subjetivação refere-se aos pares de opostos que ele encarna como fascínio e angústia, identidade e alteridade, presença e ausência, completude e falta, os quais apontam sempre para dois extremos: Vida e Morte. Nas palavras de Barthes (1977, p. 171), “... aquilo que repercute em mim, é o que aprendo com meu corpo”. Entre fascínio e angústia, o corpo impõe ao eu alguma vibração, deixando entrever - e repercutir - algum sujeito.

\section{Referências}

Assoun, P.-L. Metapsicologia freudiana: uma introdução. Rio de Janeiro: Jorge Zahar, 1996. $292 \mathrm{p}$.

BACon, F. Self-Portrait. Disponível em: <http://www.mcs.csuhayward.edu/ malek/ Pazzo.html>. Acesso em 13 de setembro de 2003.

Barthes, R. (1977). Fragmentos de um discurso amoroso. Rio de Janeiro: Francisco Alves, 1981.

A câmara clara. 7. ed. Rio de Janeiro: Nova Fronteira, 1984. 185 p.

Blanchot, M. (1955). O espaço literário. Rio de Janeiro: Rocco, 1987. 278 p.

BRANDÃo, J. S. Mitologia grega. Petrópolis: Vozes, 2002. 333 p.

Freud, S. (1911). Notas psicanalíticas sobre um relato autobiográfico de um caso de paranóia (dementia paranoides). In: Edição Standard Brasileira das Obras Psicológicas Completas de Sigmund Freud. Trad. sob a direção de Jayme Salomão. Rio de Janeiro: Imago, 1996. v. XII.

(1914). Sobre o narcisismo: uma introdução. In: Edição Standard Brasileira das Obras Psicológicas Completas de Sigmund Freud. Trad. sob a direção de Jayme Salomão. Rio de Janeiro: Imago, 1996. v. XIV.

(1919). O estranho. In: Edição Standard Brasileira das Obras Psicológicas Completas de Sigmund Freud. Trad. sob a direção de Jayme Salomão. Rio de Janeiro: Imago, 1996. v. XVII. 


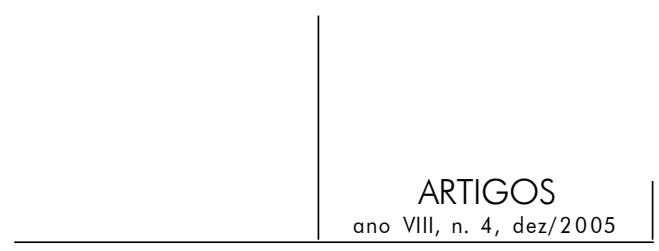

(1926 [1925]). Inibições, sintomas e angústia. In: Edição Standard Brasileira das Obras Psicológicas Completas de Sigmund Freud. Trad. sob a direção de Jayme Salomão. Rio de Janeiro: Imago, 1996. v. XX.

(1936). Um distúrbio de memória na acrópole. In: Edição Standard Brasileira das Obras Psicológicas Completas de Sigmund Freud. Trad. sob a direção de Jayme Salomão. Rio de Janeiro: Imago, 1996. v. XXII.

Guimarães Rosa, J. (1962). Primeiras estórias. 50. ed. Rio de Janeiro: Nova Fronteira, 2001. 236 p.

LACAN, J. (1946). Formulações sobre a causalidade psíquica. In: Escritos. Rio de Janeiro: Jorge Zahar, 1998. 937 p.

(1949). O estádio do espelho como formador da função do Eu. In: Escritos. Rio de Janeiro: Jorge Zahar, 1998. 937 p.

(1962-1963). O seminário. Livro X. A angústia, inédito. Trad. Centro de Estudos Freudianos de Recife.

(1964). O seminário. Livro XI. Os quatro conceitos fundamentais da psicanálise. Rio de Janeiro: Jorge Zahar, 1998. 269 p. 937 p.

(1966). De nossos antecedentes. In: Escritos. Rio de Janeiro: Jorge Zahar, 1998.

Porge, E. Sujeito. In: Kaufman, P. (ed.). Dicionário enciclopédico de psicanálise: o legado de Freud e Lacan. Rio de Janeiro: Jorge Zahar, 1996. 785 p.

QUINET, A. Um olhar a mais - ver e ser visto na psicanálise. Rio de Janeiro: Jorge Zahar, 2002. 312 p.

Rivera, T. Arte e psicanálise. Rio de Janeiro: Jorge Zahar, 2002. 75 p. (Passo-a-Passo, v. 13).

Scheinkman, D. Da pulsão escópica ao olhar: um percurso, uma esquize. Rio de Janeiro: Imago, 1995.

\section{Resumos}

Por un diálogo entre un caso clínico y una obra de arte, este artículo trata de la mirada y la imagen del cuerpo en sus relaciones con la constitución subjetiva. Se propone que la mirada sobre el cuerpo implica dos dimensiones: la facinación y la angustia, respectivamente ligadas a la identificación y a la alteridad, fundamentos de la constitución humana.

Palabras clave: Psicoanálisis, cuerpo, mirada, facinación, angustia 


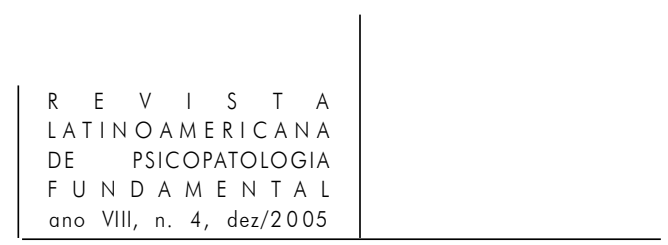

À travers le dialogue entre un cas clinique et une oeuvre d'art, cet article discute la question du regard et de l'image corporelle dans la structuration de la subjectivité. Le regard sur le corps évoquerait deux dimensions, à savoir la fascination et l'angoisse, renvoyant à l'identification et à l'altérité, fondamentales pour la constitution de l'humain.

Mots clés: Psychanalyse, corps, regard, fascination, angoisse

Weaving a dialogue between a clinical case and art, this paper discuss about the look and the body image in the constitution of the subjectivity. We propose that the look towards the body evokes two dimensions: fascination and angst, notions related respectively to identification and alterity, both essential for human constitution.

Key words: Psychoanalysis, body, look, fascination, angst 